\title{
O DIABO E A DINÂMICA DO OCIDENTE
}

\section{The devil and the dynamics of occident}

\author{
Silvia Liebel*
}

MUCHEMBLED, Robert. Uma história do Diabo: séculos XII - XX. Rio de Janeiro: Bom Texto, 2001.386 p.

Aparentemente o Demônio revela uma imagem desgastada, em grande parte pela laicização, após séculos de domínio insidioso sobre a civilização ocidental. Entretanto, o interesse pelo Maligno é não somente atual, mas crescente - a Igreja Católica reafirma sua presença e cria um novo ritual exorcista, enquanto ampliam-se as seitas satânicas.

Muchembled retoma a trajetória do mito cristão construído na Idade Média até as duas correntes contemporâneas de posicionamento perante o Mal, distintas em suas bases culturais e ramificações religiosas: a primeira, representada por França, Bélgica e países latinos, na qual o imaginário diabólico mesclou-se ao fantástico, ao burlesco; e a segunda, representada pelos Estados Unidos, Inglaterra, Alemanha e Países Baixos, na qual Satã é um perigo interno que precisa ser controlado ou destruído.

O autor amplia a visão de Jean Delumeau, ${ }^{1}$ que considera o medo de Satã intrínseco à civilização renascentista, mapeando suas modificações no imaginário ocidental e relacionando diretamente a necessidade de expulsá-lo às conquistas européias. Considerando que o "diabo é sempre filho de seu tempo" (p. 287), são traçados sua presença aterradora e alojamento no íntimo do ser humano; sua influência perniciosa, garantia do progresso e do hedonismo; e, por fim, a interiorização do Mal.

A singularidade que o Diabo e o Inferno adquirem na Idade Média, impregnada no imaginário coletivo e nos valores sociais, marca a agregação em torno do cristianismo unificador que se impunha sobre múltiplos poderes locais conflitantes. O crescimento do medo corresponde ao crescimento do poder simbólico da Igreja, que constrói a imagem do Maligno e da feiticeira num combate acirrado aos resquícios do paganismo demonizado.

* Mestranda em História - UFPR/Bolsista CNPq

1 DELUMEAU, J. História do medo no Ocidente: 1300-1800, uma cidade sitiada. São Paulo: Cia. das Letras, 1993. 
As crenças populares, tomadas como "superstições" pela religião inconteste, eram incapazes de fornecer todos os elementos que foram agrupados num universo demoníaco estruturado. Como Delumeau, Muchembled acredita na essência cristã das populações de então, mesmo com fundos culturais pagãos ainda não assimilados, numa crítica direta a Margaret Murray, que tomou o sincretismo religioso ainda presente como um elemento de distinção do cristianismo, e a Ginzburg, seguidor dos rastros da antropóloga. ${ }^{2}$

Entretanto, centrando-se na visão medieval terrificante do Diabo, Muchembled acaba por preterir seu lado sedutor quando assume aparências aliciantes e enganadoras, lembradas por Le Goff. ${ }^{3}$ As representações populares ocupam papel diminuto em sua obra, em favor de uma análise de como se deu a construção da visão elitista, mais trágica, que lentamente é assimilada pelas comunidades. O imaginário em torno do satânico atinge seu ápice com a demonologia no século XV, período marcado por conflitos internos no papado e ameaças heréticas a uma Igreja em crise.

O início do século XVI vê o medo do Diabo se intensificar, o que resulta numa implacável perseguição que só é interrompida diante de um mal maior: a Reforma. Diminui então o número de processos contra feitiçaria e a vendagem do Malleus Maleficarum, principal manual inquisitório. Apoderandose do mito criado pelos católicos, os reformadores vêem emergir nas terras de Lutero uma influente cultura de medo e desconfiança de Satã, atiçada pelo pavor da iminência do Final dos Tempos, expressa por Delumeau. ${ }^{4}$ A obsedante presença do Mal adquire tal sentido de totalidade que "dá à crença no demônio o valor de um mito cósmico explicativo". (p. 143)

A originalidade de Muchembled consiste em vincular indelevelmente ao Diabo à construção de uma identidade coletiva do Ocidente, impulsionada por contínuas transformações radicais, como a descoberta de novos povos e as reformas religiosas. A busca de sinais de amparo divino aos homens que ficaram à mercê de Satã, afligidos por pestes, fomes, cometas, é vista nas missões de evangelização e na luta contra os inimigos externos e traidores internos. Esse mundo atormentado e buscando saídas em seus próprios tormentos encontrará caminhos para a ação e

2 A esse respeito ver: GINZBURG, C. História noturna: decifrando o sabá. São Paulo: Cia. das Letras, 1991, e Os andarilhos do bem: feitiçaria e cultos agrários nos séculos XVI e XVII. São Paulo: Cia. das Letras, 1989. Neste, o autor coloca os benandanti em franca oposição à Igreja, como uma força concorrente; porém, os próprios não se pensavam assim, sendo colocados dentro do estereótipo do sabbat por força de interrogatórios sugestivos. A partir de um testemunho com alguns elementos próximos aos benandanti, Ginzburg aponta "um núcleo de crenças bastante coerente e unitário" (p. 79), mapeando semelhanças dispersas em um amplo território, conferindo-lhes uma única e ancestral origem.

3 LE GOFF, J. A civilização do Ocidente medieval. Lisboa: Estampa, 1995. v. 1

4 DELUMEAU, J. op. cit. p. 244. 
o processo civilizatório, correlacionado diretamente com a dinâmica do Ocidente de Elias. Integram esse quadro a exigência de maior rigor pessoal e a necessidade de vigiar a obscenidade do corpo, impedindo o Diabo de se apossar dele. "Este mecanismo de personalização e interiorização do pecado foi o fundamento mesmo da modernização do Ocidente". (p. 144)

Mas a retórica religiosa foi insuficiente para a inculcação do universo aterrador nas mentalidades. Desvinculando-a do domínio exclusivo da Igreja, Muchembled relaciona aos escritores e artistas, que se dirigiram às elites, a disseminação das idéias da tentação constante e das múltiplas faces de Satã notavelmente observadas na produção de Bruegel e Bosch. Assim, a cultura trágica, impulsionada pela religião e pela preservação de um sentido de rigor e moralidade, também teve sua contrapartida no campo artístico-cultural, que encontrou audiência no crescimento contínuo do público leitor. Este absorvia, em fins do período, as dúvidas sobre o elo entre um Deus bondoso e a humanidade nas histórias trágicas, que mostravam a constante vigilância divina.

Em meados do século XVII, com o fim das guerras religiosas e o avanço do racionalismo e do hedonismo, começa a diminuir a crença na realidade da bruxaria e na figura de Satã, prenúncio de sua simbolização como o Mal e do longo processo de "desencantamento do universo". Na França, com a teoria do direito divino e a separação entre político e religioso, Muchembled vê na grandiosidade do Rei-Sol um reflexo da luminosidade divina estendida sobre a terra, provocando o recuo da influência diabólica.

O século XVIII apresenta as alterações sociais que levarão à acentuação do pudor, enquanto, como em Fausto, o pecado se aloja no íntimo do homem. Surge então o gênero fantástico, no qual Satã vê seu poder diminuído e sua própria realidade questionada. Na literatura inglesa, ao contrário, observa-se o roman noir com um ambiente carregado de terror, o Diabo externo e um caminho mais longo à personalização do Mal do que na França, onde o "cristianismo da danação" não surte mais efeito num meio anticlerical. Mas isso não inibe a vulgarização do universo demoníaco, visível na literatura "frenética", com Frankenstein, de Mary Shelley, sendo dito um "demônio" - porém, foram os homens que o tornaram mau.

A aurora romântica do século XIX vê Byron tornar Lúcifer o anjo maldito e relacioná-lo indelevelmente ao espírito da revolta, como Hugo, Vigny e Delacroix o fariam. Satã adquire uma aura misteriosa, com os "poetas malditos", na esteira de Baudelaire, evocando-o. Alguns escritores dedicam-se ao estudo de processos inquisitoriais e Michelet, em A Feiticeira, inscreve a marca do Romantismo nos protestos contra o cristianismo que procurou eliminar quaisquer vestígios de paganismo. 
A moral "decadente" de Oscar Wilde, Freud e Stevenson manifesta um embaraço existencial e coloca o mal no âmago do indivíduo, buscando as trevas e o inusitado, que podemos também estender ao grotesco kafkiano. Para Muchembled, Freud anuncia o "movimento de desculpabilização do sujeito" (p. 268), e a psicanálise, $O$ médico e o monstro e os estudos de Charcot sobre a histeria feminina trazem à tona mais do que o demônio interior, "a face sombria, reprimida, do sujeito". (p. 259)

Observamos com a Modernidade o abalo da Igreja e do Estado como sistemas normatizadores da vida social, enquanto surgem movimentos de junção social, como o nacionalismo e o marxismo, e de promoção dos direitos individuais, com as Ciências Humanas atuando nos dois sentidos, "filhas do diabo". Como conseqüência do recuo das imposições religiosas, da falência do comunismo e da "ascensão do irracional", abrem-se novos caminhos para se pensar o Mal no século XX, relativizando o Diabo ou adequando-o ao pensamento individual, o que fragiliza a ortodoxia religiosa.

A "tendência apaziguadora" compartilhada por franceses, belgas e latinos reflete a banalização da temática demoníaca, envolvendo o Tinhoso num contexto de sarcasmo, busca do prazer e de valorização do indivíduo. ${ }^{5} \mathrm{Na}$ França, com o laicismo prevalecendo, o Diabo não é nada mais que a maldade humana; na Bélgica mantém-se a tradição que evoca o insólito, o anticonformismo e o "terror de existir".

A "tendência angustiante", observada nos Estados Unidos e na Europa Setentrional, é repleta de pessimismo. A Inglaterra de Bram Stocker, Robert Louis Stevenson, Agatha Christie e Alfred Hitchcock crê no Demônio arrasador dos destinos humanos; entretanto, nas obras do católico mestre do suspense, o mal não é exterior ao sujeito, aloja-se em seu íntimo, com a expectativa mantendo a angústia.

$\mathrm{Na}$ Alemanha a presença demoníaca é mais forte: os ecos da Primeira Guerra Mundial levaram a refletir nas telas a angústia em Nosferatu (1922), Fausto (1926) e Metrópolis (1927). Após a Segunda Guerra, o

sentimento coletivo de culpa dos alemães (...) reforçou ainda mais sua afinidade com americanos habituados a carregar o complexo de Salém, que consiste em destruir todo ímpio e não sofrer por

5 Acrescentaria nessa linha a América Latina, ignorada pelo autor, que viu no início de sua colonização o vulto negro de Satã se abatendo sobre os trópicos, na evangelização que sobrepôs o cristianismo às crenças nativas. Contudo, os ecos do Iluminismo foram vitoriosos nas colônias e, apesar da crescente proliferação de igrejas evangélicas nos inícios do novo século, o Diabo continua vinculado ao prazer, à liberdade individual e, destacadamente, ao erotismo. 
vezes com uma culpa retrospectiva, perguntando-se se eles tinham razão ou não. (p. 331)

A cultura cinematográfica norte-americana é analisada pelo autor francês, que a vincula à elevação de inimigos visíveis para suprir o demônio exterior, com uma obsedante busca de indícios da presença do Mal transportada para as telas e HQ, na forma de vampiros, bruxas, lobisomens ou do insólito da série televisiva Arquivo $X$.

Dominar a parte maldita do ser faz parte do sonho americano. (...)Trata-se de uma via original de dominação da violência, sem utilizar um Estado regulador capaz de monopolizá-la, sem limitar as míticas liberdades herdadas dos pioneiros, particularmente a mística das armas, com uma dupla diferença em relação à Europa, em que o processo civilizatório se alicerçou conjuntamente no desarmamento físico e em um forte controle psíquico dos cidadãos. (p. 339-340)

O cinema reveste o Maligno de múltiplas aparências, vivenciando cada momento histórico: ele é o inimigo à espreita nos filmes noirs durante a Crise de 29 , preteridos pelos de gangsters quando a criminalidade assolava os anos 30 . A Segunda Guerra garantiu o enfoque dos japoneses e alemães ameaçadores das forças do Bem, e, passado o trauma nazista, vemos as lentes se deslocarem na Guerra Fria para o diabolizado inimigo vermelho, em filmes sobre invasores alienígenas e espionagem. Na persecutória cultura americana, em que a figura demoníaca é indispensável para separar os indivíduos bons dos maus, "Salém é declinado em todas as suas formas, o que agrada pela perenidade de uma poderosa síndrome de angústia em relação à invasão maléfica, adaptada às mutações da sociedade.” (p. 322)

A Guerra do Vietnã reflete nas telas um mal-estar geral, corroborado pelo assassinato de Kennedy e pelo crescimento do poder bélico soviético. Somente com Guerra nas estrelas e Contatos imediatos de terceiro grau, ambos de 1977, a nação obtém um efeito tranqüilizador. Ao lado da ficção científica, filmes de terror atraíam intensamente o público americano na década de 1970; Muchembled observa que, para essa atração mórbida pela catástrofe, "um mecanismo de liberação da angústia latente parece ser a principal explicação, o que significa que o medo do demônio (...) constituía 
sempre uma importante estrutura psíquica para grande parte da população." (p. 324)

Neste momento, em que seitas luciferianas expandem seus domínios e provocam comoções nacionais, ${ }^{6}$ ocorre uma ruptura no satanismo ignorada pelo autor, que lhe confere uma única diretriz, na qual se confundem vestígios folclóricos e a influência cultural norte-americana. Para C. Nogueira, os assassinatos cometidos por seguidores de Charles Manson, um inculto obcecado pelo macabro, marcam a separação do satanismo elitista em busca de conhecimentos do ocultismo. Entretanto, esses escândalos seriam exceções, quando a busca pelo sobrenatural e produtos esotéricos é crescente, acomodada à sociedade de consumo. ${ }^{7}$ Poderíamos assim contrapor um eruditismo e elitismo satânico contemporâneo ao caracterizado pacto demoníaco medieval no intuito de fugir das privações.

Ainda é abordado o cinema hollywoodiano, que explora o heroísmo americano em filmes como Godzilla (1956), Marte Ataca! (1996) e Armagedon (1998), com o autor vendo nos EUA, diferentemente da Europa, a responsabilidade individual de contribuir para a segurança do mundo, ao que se acrescenta a incerteza da salvação divina. Acrescentamos a necessidade de explorar as raízes desse sustentáculo no fundamentalismo cristão norteamericano do século XIX, que confere aos Estados Unidos o papel de "polícia do mundo".

Felizmente, graças a Deus, nada resiste aos novos super-homens que defendem a melhor civilização do mundo. Com a condição, naturalmente, de que sejam restaurados os puros valores fundadores da nação. O demônio com certeza... Se ele não existisse, seria preciso inventá-lo, para manter agregada uma sociedade que não tem mais um inimigo exterior à sua altura. (p. 330)

Muchembled finaliza seu estudo com a crença de que o impulso conferido por Satã à Europa Moderna concede hoje aos Estados Unidos a supremacia mundial. Entretanto, o fim da União Soviética privou os americanos

6 Como o assassinato de cinco pessoas por fiéis da Final Church em 1969, entre elas Sharon Tate, a esposa grávida de Roman Polanski, diretor de O bebê de Rosemary (1968). O casal era amigo íntimo do popular satanista Anton La Vey, que chegou mesmo a representar o Diabo no polêmico filme. Não foram encontradas ligações entre o crime e a produção da obra.

7 NOGUEIRA, C. R. F. O nascimento da bruxaria: da identificação do inimigo à diabolização de seus agentes. São Paulo: Imaginário, 1995. p. 196-200. 
de seu inimigo externo, visível, contra o qual todas as armas se voltam, deixando um vazio em seu imaginário. Acrescentaríamos, à luz dos acontecimentos recentes, a elevação de um novo alvo diabólico para as pulsões americanas: a imagem é transferida ao inimigo árabe não-submisso, encarnado nas figuras de Osama Bin Laden e de Saddam Hussein. Contudo, a perenidade dessa construção somente poderá ser analisada com uma confluência maior de estudos históricos, sociológicos e psicanalíticos que venham complementar a brilhante análise de Muchembled.

\section{Referências}

DELUMEAU, J. História do medo no Ocidente: 1300-1800, uma cidade sitiada. São Paulo: Cia. das Letras, 1993.

GINZBURG, C. História noturna: decifrando o sabá. São Paulo: Cia. das Letras, 1991. . Os andarilhos do bem: feitiçaria e cultos agrários nos séculos XVI e XVII. São Paulo: Cia. das Letras, 1989.

LE GOFF, J. A civilização do Ocidente medieval. Lisboa: Estampa, 1995. v. 1.

NOGUEIRA, C. R. F. O nascimento da bruxaria: da identificação do inimigo à diabolização de seus agentes. São Paulo: Imaginário, 1995. 